\title{
Differential expressional analysis of serum microRNAs in hepatitis $C$ patients of Quetta, Pakistan
}

\author{
Naseebullah Barozai ${ }^{1}$, Muhammad Younas Khan Barozai ${ }^{2 *}$, Muhammad \\ Din $^{2}$ and Asim Iqbal ${ }^{1}$ \\ 1. Department of Zoology, University of Balochistan Quetta-Pakistan \\ 2. Department of Botany University of Balochistan Quetta-Pakistan \\ *Corresponding author's email: barozaikhan@gmail.com \\ Citation \\ Naseebullah Barozai, Muhammad Younas Khan Barozai, Muhammad Din and Asim Iqbal. Differential expressional \\ analysis of serum microRNAs' in hepatitis C patients of Quetta, Pakistan. Pure and Applied Biology. Vol. 7, Issue 2, \\ pp853-862. http://dx.doi.org/10.19045/bspab.2018.700104
}

\begin{tabular}{llll}
\hline \hline Received: 05/05/2018 & Revised: 05/06/2018 & Accepted: 07/06/2018 & Online First: 10/06/2018 \\
\hline
\end{tabular}

\section{Abstract}

Hepatitis $\mathrm{C}$ is a liver damaging disease caused by hepatitis $\mathrm{C}$ virus (HCV) that has RNA based genome with single stranded structure and positive sense orientation. Chronic infection of HCV increases the risk of cirrhosis and hepatocellular carcinoma (HCC). MicroRNAs (miRNAs) are tiny, non-coding and regulatory RNAs, which are produced by the cell to manage posttranscriptional gene regulation. These miRNAs have been reported for helping the host's cells against invading viruses. The current research is aimed to analyze 15 miRNAs, selected because of their significance from liver perspective, for differential expression in Hepatitis C Patients of Quetta, Pakistan. The selected 15 miRNAs through literature survey are hsa miR-17, 18a, 20, 21, 24, 92a, 122, 183, 190a, 223, 296, 320c, 483, 642b and 3917. For differential expressional analysis, total RNAs from serum of hepatitis $\mathrm{C}$ patient and healthy person were extracted and subjected to stem-loop RT-PCR (reverse transcriptional-PCR) for the selected 15 miRNAs and GAPDH-as housekeeping gene. The 10 miRNAs; hsa-mir-18a, 21, 24, 183, 190a, 296, 320c, 483, 642b and 3917 are observed with over-expression, while the five miRNAs; hsa-mir-17, 20, 92, 122 and 223 with down-regulation in hepatitis $\mathrm{C}$ patient. Hepatitis $\mathrm{C}$ responding serum miRNAs could be utilizable to diagnose the disease at an early stage and better manage its treatment.

Keywords: HCV; microRNAs; RT-PCR

\section{Introduction}

One of the main cause of liver's chronic infection is hepatitis $\mathrm{C}$ virus (HCV). $\mathrm{HCV}$ is a single stranded RNA virus and its chronic infection rises the risk of cirrhosis and hepatocellular carcinoma (HCC). Its RNAbased genome is 9.6 kilobases in size and translates into a single polyprotein composed of 3011 amino acid molecules [1]. HCV initially stage with almost no symptoms but later showed some mixed symptoms as; muscular fatigue, joint pain, abdominal pain, jaundice, fatigue, blackish urine color, nausea and illness. Hepatitis $C$ has a highest prevalence in North Africa and South Asia with estimated infected people of 130-200 million worldwide. Nearly 400,000 people 
die each year from hepatitis $\mathrm{C}$, mostly from cirrhosis and hepatocellular carcinoma [2]. MicroRNAs (miRNAs) are small RNAs with regulatory role in a cell at post-transcriptional stage. They are non-protein coding, synthesized endogenously by cells with merely 18 to 26 nucleotides (nts) in length [3]. A sum of almost $30 \%$ entire gene set in human is under regulation of the miRNAs, which is a very valid confirmation of its importance in maintaining of life processes [4]. The miRNAs' appearance have been reported with cell, tissue and organ specific expression, showing chronological stages expression with as well as significant role in several biological procedures, such as development, differentiation, proliferation, response to biotic and abiotic stresses and establishment of pathological states [4-6]. Late stage diagnosis of $\mathrm{HCV}$ is one of the main reason that several patients fail to respond to current antiviral therapies [7]. Thus, non-invasive approaches to detect the $\mathrm{HCV}$ at an early stage of alterations in hepatic function are desired today. One of such method is to measure differential expressional patterns of miRNAs present in the serum of infected patients. The alteration in the expression of specific miRNAs, in response of a viral invasion, by the host cell is a key area of gene regulation research these days. The present research is aimed to analyze the important selected serum microRNAs differential expressional behavior in hepatitis C Patients of Quetta, Pakistan. These findings will serve as biomarkers for the non-invasive based early detection of the disease.

\section{Materials and methods}

Selection of the important HCV differentially expressed miRNAs

A comprehensive literature survey is carried out to find and select the important miRNAs showing differential expressional behavior to HCV. Initially a list of nearly 30 such miRNAs were identified, which resulted into a final selection of fifteen (15) important miRNAs. The selected miRNAs are hsa-mir17, 18a, 20, 21, 24, 92a, 122, 183, 190a, 223, 296, 320c, 483, 642b and 3917, which were identified and selected based on best differentially expressed miRNAs [8-11]. Glyceraldehyde 3-phosphate dehydrogenase (GADPH) [12] is used as housekeeping gene in this study. The 15 final selected miRNAs were subjected to stem-loop primers designing as shown in (Table 1), by using bioinformatics tool "Primer3" publically available at http://bioinfo.ut.ee/primer30.4.0/.

\section{Blood sampling}

Four blood (serum) samples of the hepatitis $\mathrm{C}$ patients, two male and two female genders, diagnosed and confirmed by experienced pathologists for $\mathrm{HCV}$ and showing the positive test for viral hepatitis $\mathrm{C}$ antibody screening were collected from outdoor patients of Bolan medical college hospital, Quetta, Balochistan- Pakistan. Their ages were ranged from 24-55 years. The control (healthy) bloods sampling were done from the healthy, non- hepatitis $\mathrm{C}$ and $\mathrm{HCV}$ negative volunteer students and scholars of the University of Balochistan Quetta. All the blood samples, in anticoagulant tubes, were stored at $-20^{\circ} \mathrm{C}$ in a freezer of Molecular Biology and Bioinformatics Lab (MBBL) of the Department of Botany, University of Balochistan Quetta.

\section{RNA isolation and making of cDNAs}

Total RNAs from blood-serum samples of hepatitis $\mathrm{C}$ patient and volunteer healthy persons were isolated using Trizol scheme. Briefly, $1 \mathrm{ml}$ Trizol reagent was added to a 1.5 $\mathrm{ml}$ tube containing $0.4 \mathrm{ml}$ of the sample, vortex for 20-30 second and incubated on ice for 15 minutes. The tubes were centrifuged at $13000 \mathrm{~g}$ for 10 minutes at $4^{\circ} \mathrm{C}$. The supernatant was extracted first with an equal volume of Chloroform Isoamyl alcohol (CI) $(24: 1, \mathrm{v} / \mathrm{v})$ and secondly with an equal volume of Phenol Chloroform Isoamyl (PCI) 
$(25: 24: 1 \mathrm{v} / \mathrm{v} / \mathrm{v})$. The total RNA was precipitated from the upper aqueous layer by twice volume of a $100 \%$ ice chilled ethanol. The RNA pellet was dissolved in $50 \mu 1$ DEPC treated water and stored at $-20{ }^{\circ} \mathrm{C}$. Quantitative and qualitative analyses of RNAs were performed by measuring optical density at $260 \mathrm{~nm}$ and $280 \mathrm{~nm}$ using Genova Nano spectrophotometer. Total RNAs integrity were checked by loading and running on a $1 \%$ agarose gel and visualized under UV light for ribosomal RNA bands. The cDNAs from the $1 \mu \mathrm{g}$ hepatitis $\mathrm{C}$ patient and control total RNAs were synthesized by using the Thermo Scientific ${ }^{\mathrm{TM}}$ RevertAid $^{\mathrm{TM}}$ $\mathrm{H}$ Minus First Strand cDNA Synthesis Kit, according to supplier's protocol.

Table 1. The fifteen human selected miRNAs' primers for RT-PCR expression analysis in hepatitis C patients from Quetta, Pakistan. The selected miRNAs, their primers, Tm (melting temperature), GC percentage (GC\%) and the product size (in base pair, bp) are shown here

\begin{tabular}{|c|c|c|c|c|}
\hline miRNA & Primers (5-3) & $\mathbf{T m}$ & GC\% & $\begin{array}{l}\text { Product } \\
\text { size (bp) }\end{array}$ \\
\hline hsa-mir-17 & $\begin{array}{l}\text { CCCCATTAGGGATTATGCTG } \\
\text { GCTACAAGTGCCTTCACTGC }\end{array}$ & $\begin{array}{l}59 \\
59\end{array}$ & $\begin{array}{l}50 \\
55\end{array}$ & 204 \\
\hline hsa-mir-18a & $\begin{array}{l}\text { GCAGTGAAGGCACTTGTAGC } \\
\text { TGCCAGAAGGAGCACTTAGG }\end{array}$ & $\begin{array}{l}59 \\
60\end{array}$ & $\begin{array}{l}55 \\
55\end{array}$ & 164 \\
\hline hsa-mir-20a & $\begin{array}{l}\text { CTGATGGTGGCCTGCTATTT } \\
\text { ACAGTTTGATTGGGCGACAG }\end{array}$ & $\begin{array}{l}60 \\
61\end{array}$ & $\begin{array}{l}50 \\
50\end{array}$ & 222 \\
\hline hsa-mir-21 & $\begin{array}{c}\text { TGTTTTGCCTACCATCGTGA } \\
\text { AAGTGCCACCAGACAGAAGG }\end{array}$ & $\begin{array}{l}60 \\
60 \\
\end{array}$ & $\begin{array}{l}45 \\
55\end{array}$ & 221 \\
\hline hsa-mir-24 & $\begin{array}{l}\text { CGCGGTGAACTCTCTCTTGT } \\
\text { ACGAAGGCTTTTTGCTCAAG }\end{array}$ & $\begin{array}{l}61 \\
60\end{array}$ & $\begin{array}{l}55 \\
45\end{array}$ & 214 \\
\hline hsa-mir-92a & $\begin{array}{l}\text { GCCCAATCAAACTGTCCTGT } \\
\text { ACCGATCCCAACCTGTGTAG }\end{array}$ & $\begin{array}{l}59 \\
60\end{array}$ & $\begin{array}{l}50 \\
55\end{array}$ & 173 \\
\hline hsa-mir-122 & $\begin{array}{l}\text { CCCGTGATGCTTCTTTTCTC } \\
\text { CCATTGTCACACTCCACAGC }\end{array}$ & $\begin{array}{l}60 \\
60\end{array}$ & $\begin{array}{l}50 \\
55\end{array}$ & 150 \\
\hline hsa-mir-183 & $\begin{array}{l}\text { CTTGTGAAGAGGTGGGATGG } \\
\text { CTTGTGAAGAGGTGGGATGG }\end{array}$ & $\begin{array}{l}60 \\
60 \\
\end{array}$ & $\begin{array}{l}55 \\
50 \\
\end{array}$ & 235 \\
\hline hsa-mir-190a & $\begin{array}{l}\text { ATCGGAGTTGCTGCAAAAGT } \\
\text { TATTAGGAACCCCCGGAGAC }\end{array}$ & $\begin{array}{l}60 \\
60\end{array}$ & $\begin{array}{l}45 \\
55\end{array}$ & 199 \\
\hline hsa-mir-223 & $\begin{array}{l}\text { TCACTTCCCCACAGAAGCTC } \\
\text { GTATCCAGCTGGCAGTCCAT }\end{array}$ & $\begin{array}{l}60 \\
60\end{array}$ & $\begin{array}{l}55 \\
55\end{array}$ & 184 \\
\hline hsa-mir-296 & $\begin{array}{c}\text { GGGAGGTGAGGAGAAAGGAC } \\
\text { GAGTTCACCATTCCCCAGTG }\end{array}$ & $\begin{array}{l}60 \\
60\end{array}$ & $\begin{array}{l}60 \\
55\end{array}$ & 219 \\
\hline hsa-mir-320c & $\begin{array}{c}\text { CAAACAGGCATGTGACATACAA } \\
\text { CCCAGCTTTTCCTGACTCTG }\end{array}$ & $\begin{array}{l}59 \\
62\end{array}$ & $\begin{array}{l}41 \\
55\end{array}$ & 117 \\
\hline hsa-mir-483 & $\begin{array}{c}\text { GGAAAGAAGGGAGTGGTTCC } \\
\text { GTCCCTGAGCTTGGACTCTG }\end{array}$ & $\begin{array}{l}60 \\
60\end{array}$ & $\begin{array}{l}55 \\
60\end{array}$ & 153 \\
\hline hsa-mir-642b & $\begin{array}{c}\text { GTGGGACCAGGAAGTTCTCA } \\
\text { GAGGGAGAGGAACGGAAAAT }\end{array}$ & $\begin{array}{l}60 \\
60 \\
\end{array}$ & $\begin{array}{l}55 \\
50\end{array}$ & 203 \\
\hline hsa-mir-3917 & $\begin{array}{l}\text { TACACTTCCCGAGGTGCTTC } \\
\text { GACCACACTCTGAGCACCAA }\end{array}$ & $\begin{array}{l}60 \\
60\end{array}$ & $\begin{array}{l}55 \\
55\end{array}$ & 174 \\
\hline
\end{tabular}




\section{Differential Expressional Analysis}

The $80 \mathrm{ng}$ of cDNAs from hepatitis $\mathrm{C}$ patients and control samples were used as templates for PCR. The PCR was programmed as; Initial denaturation at $95^{\circ} \mathrm{C}$ for 3 minutes followed by 35 cycles of denaturation $94^{\circ} \mathrm{C}$ for 35 seconds, annealing at $60^{\circ} \mathrm{C}$ for 25 seconds and extension at $72^{\circ} \mathrm{C}$ for 35 seconds and a final elongation step at $72^{\circ} \mathrm{C}$ for 10 minutes. The PCR products were separated, run and checked on $2.0 \%(\mathrm{w} / \mathrm{v})$ agarose gel with 100bp DNA ladder. The gel images were saved.

\section{Results and discussion}

Significant findings in various organisms have been reported through the study of differentially expressed RNAs [13, 14]. In the current study, a set of the 15 important miRNAs, showing a valid differential expressional behavior to $\mathrm{HCV}$, were selected through a comprehensive literature survey and subjected to the RT-PCR expressional analysis in hepatitis C patients' serum of Quetta, Pakistan. These fifteen (15) miRNAs were hsa-mir-17, 18a, 20, 21, 24, 92a, 122, 183, 190a, 223, 296, 320c, 483, 642b and 3917. A particular mechanism of interplay between miRNAs and HCV could be revealed through analyzing differentially expressed miRNAs in response to HCV by host cells. Such findings will facilitate for devising new molecular techniques with novel diagnosis and therapeutic approaches in hepatitis $\mathrm{C}$ patients.

\section{Over-Expressed miRNAs}

The cDNAs made from the total RNAs of hepatitis $\mathrm{C}$ patients and healthy persons were analyzed to investigate differential expressional of the selected 15 miRNAs along with the housekeeping gene, i-e. GAPDH. The ten off fifteen miRNAs were observed with over-expressed differential expression response to $\mathrm{HCV}$ in hepatitis $\mathrm{C}$ patients' serum of Quetta-Pakistan (Figure 1). These ten miRNAs were hsa-mir-18a, 21,
24, 183, 190a, 296, 320c, 483, 642b and 3917.

Over-expression of miR-17-92 cluster is reported as a crucial oncogenic expressional event in different cancer types including lung, breast, colon, pancreas, prostate, thyroid, and lymphoma and hence named as oncomiR-1. This oncomiR cluster is positioned in an intronic region of chromosome 13 [15]. Its primary transcript is almost $0.8-\mathrm{kb}$ in size and polycistron, which resulted into seven different mature miRNAs: miR-17 (miR-17-5p and miR-17-3p), miR18a, miR-19a, miR-19b, miR-20a, and miR92a. Four of them miRNAs 17, 18a, 20a and 92a were selected and studied in this research project.

This first miRNA studied in this research is miR-18a, which is a member of the miR-1792 cluster and is reported as an oncogenic miRNA in nasopharyngeal carcinoma [16], breast cancer [17] and pancreatic cancer [18]. On the other hand the same miRNA, miR-18a is also reported to suppress cell proliferation in bladder cancer T24 cells [19]. This is suggesting that miR-18a could has diverse roles in different kinds of diseases by targeting various genes. The identification of up-regulation for miRNA 18a in hepatitis C patients' serum of Quetta-Pakistan confirming its role in $\mathrm{HCV}$ infection and could be used as molecular marker for early diagnosis.

Similarly, the miR-20 is another important member of the miR-17-92 cluster causing many malignancies and hence denoted as oncomirs [20, 21]. In this study, the hsa-mir20 has also showed over-expression in hepatitis C patients of Quetta, Pakistan and it confirmed that the mir-20 is causing hepatocellular carcinoma or chronic hepatitis in the Quetta's HCV patients. So, by developing an approach to downregulate the miR-20 in HCV patients would be a good initiative to suppress the growth of 
hepatocellular carcinoma or chronic hepatitis [22].

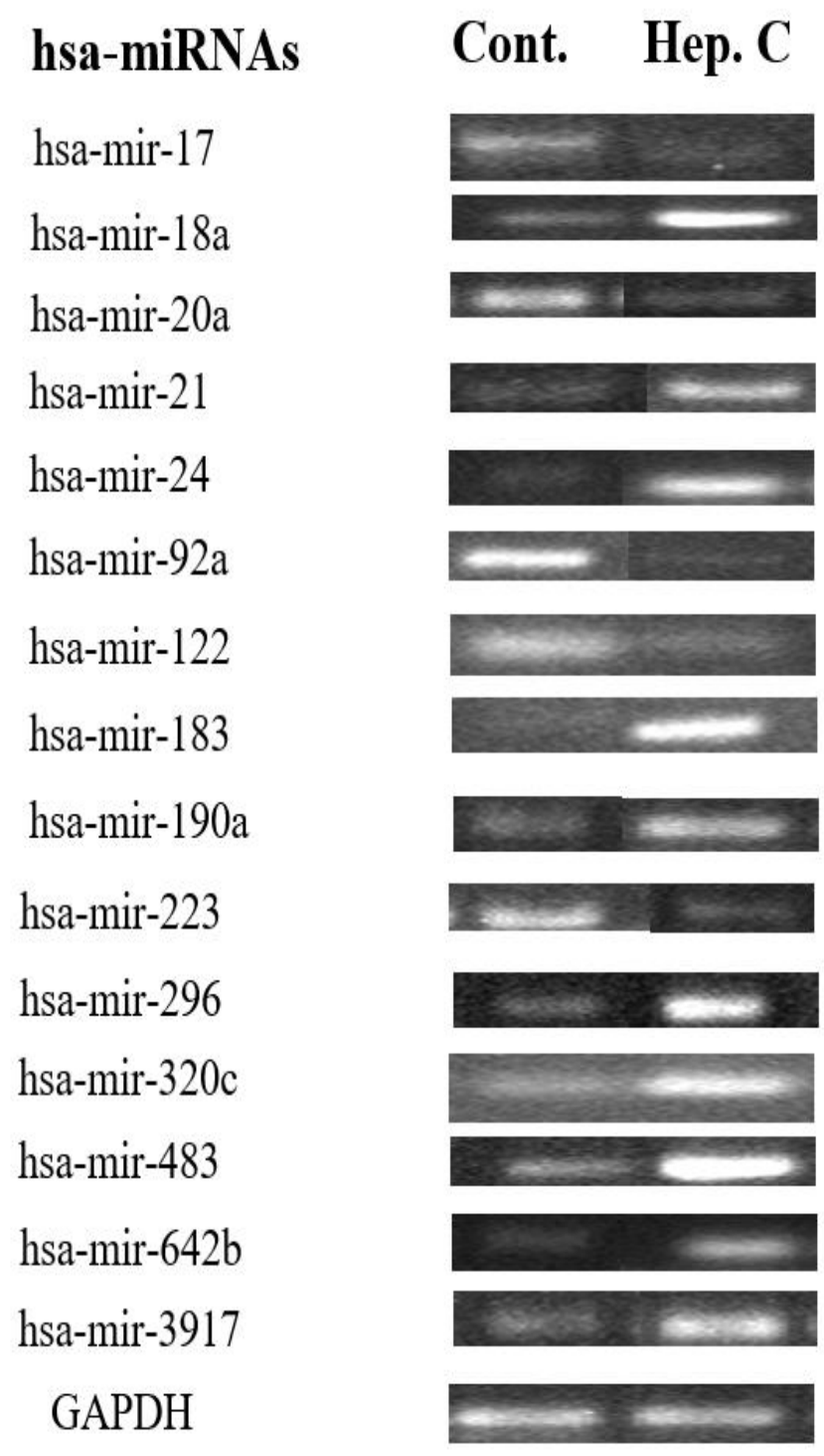

Figure 1. Experimental analysis of the selected human miRNAs in hepatitis $C$ patients from Quetta, Pakistan by RT-PCR. The fifteen human significant miRNAs and a GAPDH-as housekeeping gene, were subjected to the expression analysis through RT-PCR. The ten miRNAs; hsa-mir-18a, 21, 24, 183, 190a, 296, 320c, 483, 642b and 3917 are observed with over-expression, while five miRNAs; hsa-mir-17, 20, 92, 122 and 223 with down-regulation in hepatitis $\mathrm{C}$-patients.

One of the pioneer miRNA reported for overexpression in mammalian malignancy is miR-21. It is also the most often overexpressed miRNAs in solid tumors [23]. The mir-21 involvement also in heart and lungs diseases such as cardiac and pulmonary fibrosis along with myocardial infarction has been evidenced during many immunological and developmental processes [24]. The hsamir-21, selected for the differential 
expressional analysis in this study is also seen with up-regulation under $\mathrm{HCV}$ infection in hepatitis C patients' serum of QuettaPakistan (Figure 1). Due to its main role by targeting the genes involved in the cell communication processes, miR-21 would be a good potential candidate for genetic and pharmacological modulation in various diseases including hepatitis $\mathrm{C}$.

Another up-regulated miRNA found in hepatitis $\mathrm{C}$ patients' serum infected by $\mathrm{HCV}$ is has-miR-24. The miR-24 is regularly overe-xpressed through terminal differentiation of hematopoietic cell lines that leads to various lineages [25]. Qin et al. [26] found that apoptosis is being regulated by the miR-24 to target Fas associated factor (FAF1) in human prostate cancer cell line (DU-145) and suggest that miR-24 could be an effective drug target for treatment of hormone-insensitive prostate cancer or other types of cancers. Recently KhodadadiJamayran, et al. [27] reported that miR-24-3p has more expression in patients with metastases, both in plasma and in breast cancer tissues. They also reported that cancer, breast cancer and proteoglycans were the main three pathways affected by miR-24$3 p$ up-regulation. Yan et al. [28] found that SOX7, a transcription factor belongs to Sryrelated high-mobility group [HMG] box genes is being targeted by miR-24-3p and stimulates cell proliferation and migration in lung cancer of xenograft mice suggesting its role as an oncomiR in lung cancer by regulating SOX7. The finding of same miRNA, i-e, mir-24 with up-regulation in this study suggest that it could be used as biomarker for the early diagnosis of $\mathrm{HCV}$ infection.

The others miRNAs such as mir-183, 190a, 296, 320c, 483, 642b and 3917 showing upregulation in hepatitis $C$ patients' serum of Quetta-Pakistan were also reported with over-expression in HCC patients (miR-183) [29], in patients with non-small cell lung cancer (miR-183) [30], in most pancreatic cancer tissues and cell lines (miR-190) [31], in bladder cancer (miR-190) [32], in esophageal carcinoma (miR-296) [33], in ovarian cancer (miR-320) [34], in liver cancer cells (miR-483) [35], in pancreatic cancer (miR-642) [36] and in lung cancer (miR-3917) [37]. Based on increased expression, these miRNAs can be used as molecular predictive markers for the early diagnosis of HCV infection.

\section{Repressed miRNAs}

Out of 15 miRNAs, studied for differential expressional analysis in hepatitis $C$ patient of Quetta-Pakistan, five miRNAs as hsa-mir-17, 20, 92, 122 and 223 were found with downregulation. Three off them, miR-17, 20 and 92 are the members of the miR-17-92 cluster and reported with up-regulation in many cancers [15]. The down-regulation of these miRNAs in this study may be due to the interferon treatment of the patients and or different type of cancer or HCV genotype. This also suggest re-evaluating these three miRNAs before and after the treatment in hepatitis $\mathrm{C}$ patients, different type of cancers and $\mathrm{HCV}$ genotype .

The most abundant miRNA that counts almost $70 \%$ of the total population in liver is miR-122 [38]. Besides liver, a minor expression in the heart cells has been also reported [39], but still it is considered as one of the liver-specific miRNA. The miR-122 expression in $\mathrm{HCC}$ has been reported by many researchers for down-regulation [4042]. The miRNA-122 because of all these importance in liver related expression drive us to study it in hepatitis C patients of QuettaPakistan. As the other researchers' findings, we also found it as a repressed miRNA in hepatitis C patients of Quetta-Pakistan, suggesting it could be used as therapeutic candidate for the treatment of $\mathrm{HCV}$.

A specific expression in the haematopoietic system for miRNA-223 has been reported under a control of an independent promoter 
[43]. Fazi et al. [44] reported downregulation of the miR-223 in acute myeloid leukaemia (AML) that has been done through chromatin remodeling, an epigenetics approach. The miR-223 was also found repressed in chronic lymphoid leukaemia [45]. In contrast to our findings that miR-223 is down-regulated in hepatitis $\mathrm{C}$ patients of Quetta-Pakistan, recently Wei et al. [46] observed that the miR-223 was significantly upregulated in clinical samples and cell lines of colon adenocarcinoma. This suggest that different expressional behavior is exist for the same miRNA in various cancer types.

\section{Conclusion}

As per the best of our knowledge, this is the pioneer research report about the differential expressional analyses of the fifteen most significant miRNAs in the hepatitis $C$ patients' serum from Quetta, Pakistan. The observation of the ten over-expressed and five repressed miRNAs from the serum of hepatitis $\mathrm{C}$ patients, reported in this manuscript, could be utilized to devise new miRNAs-based molecular diagnosis and therapeutics tools for an early stage and better cure of the disease and HCV infection.

\section{Author's Contributions}

Conceived and designed the experiments: MYK Barozai \& A Iqbal, Performed the Experiments: N Barozai \& M Din, Analyzed the data: MYK Barozai, N Barozai \& M Din, Contributed reagents/ materials/ analysis tools: MYK Barozai, Wrote the paper: N Barozai, MYK Barozai \& M Din

\section{References}

1. Penin F, Dubuisson J, Rey FA, Moradpour D \& Pawlotsky JM (2004). Structural biology of hepatitis $\mathrm{C}$ virus. Hepatology 39(1): 5-19.

2. World Health Organization website, accessed April-2018

3. Bibi F, Barozai MYK \& Din M (2017). Bioinformatics profiling and characterization of potential microRNAs and their targets in the genus Coffea. Turk J Agric Forest 41(3): 191-200.

4. Lewis BP, Burge CB \& Bartel DP (2005). Conserved seed pairing, often flanked by adenosines, indicates that thousands of human genes are microRNA targets. Cell 120(1): 15-20.

5. Barozai MYK \& Din M (2017). Initial screening of plant most conserved MicroRNAs targeting infectious viruses: HBV and HCV. In Applied Sciences and Technology (IBCAST), 2017 14th International Bhurban Conference on (pp. 192-196). IEEE.

6. Jahan S, Barozai MYK, Din M, Achakzai H \& Sajjad A (2017). Expressional studies of microRNAs in Hepatitis B Patients of Quetta, Pakistan. Pure Appl Biol 6(3): 1044-1052.

7. Fields BN, Knipe DM, Howley PM. Fields virology. 5th ed. Philadelphia: Wolters Kluwer Health/Lippincott Williams \& Wilkins; 2007.

8. Devhare PB, Steele R, Di Bisceglie AM, Kaplan DE \& Ray RB (2017). Differential expression of MicroRNAs in Hepatitis $\mathrm{C}$ Virus-mediated liver disease between African Americans and Caucasians: implications for racial health disparities. Gene Expr 17(2): 8998.

9. Gupta P, Cairns MJ \& Saksena NK (2014). Regulation of gene expression by microRNA in HCV infection and HCV-mediated hepatocellular carcinoma. Virol J 11(1): 64.

10. Shwetha $S$, Gouthamchandra $K$, Chandra M, Ravishankar B, Khaja MN \& Das S (2013). Circulating miRNA profile in HCV infected serum: novel insight into pathogenesis. Scientific Rep 3: 1555.

11. Akamatsu S, Hayes CN, Tsuge M, Miki D, Akiyama R, Abe H, Ochi H, Hiraga N, Imamura M, Takahashi S \& Aikata H (2015). Differences in serum microRNA 
profiles in hepatitis $\mathrm{B}$ and $\mathrm{C}$ virus infection. J Infec 70(3): 273-287.

12. Barber RD, Harmer DW, Coleman RA \& Clark BJ (2005). GAPDH as a housekeeping gene: analysis of GAPDH mRNA expression in a panel of 72 human tissues. Physiol Genom 21(3): 389-395.

13. Barozai MYK \& Wahid HA (2012). Insilico identification and characterization of cumulative abiotic stress responding genes in Potato (Solanum tuberosum L.). Pak. J. Bot 44: 57-69.

14. Wahid HA, Barozai MYK \& Din M (2016). Functional characterization of fifteen hundred transcripts from Ziarat juniper (Juniperus excelsa M. Bieb). Adva Life Sci 4(1): 20-26.

15. Fuziwara CS \& Kimura ET (2015). Insights into regulation of the miR-17-92 cluster of miRNAs in cancer. Front Medic 2, 64.

16. Luo Z, Dai Y, Zhang L, Jiang C, Li Z, Yang J, McCarthy JB, She X, Zhang W, Ma J \& Xiong W (2012). miR-18a promotes malignant progression by impairing microRNA biogenesis in nasopharyngeal carcinoma. Carcinogen 34(2): 415-425.

17. Castellano L, Giamas G, Jacob J, Coombes RC, Lucchesi W, Thiruchelvam P, Barton G, Jiao LR, Wait R, Waxman J \& Hannon GJ (2009). The estrogen receptor- $\alpha$-induced microRNA signature regulates itself and its transcriptional response. Proc Nation Acad Sci 106(37): 15732-15737.

18. Morimura R, Komatsu S, Ichikawa D, Takeshita H, Tsujiura M, Nagata H, Konishi H, Shiozaki A, Ikoma H, Okamoto K \& Ochiai T (2011). Novel diagnostic value of circulating miR-18a in plasma of patients with pancreatic cancer. Brit J Can 105(11): 1733.
19. Tao J, Wu D, Li P, Xu B, Lu Q \& Zhang W (2012). microRNA-18a, a member of the oncogenic miR-17-92 cluster, targets Dicer and suppresses cell proliferation in bladder cancer T24 cells. Mol Med Rep 5(1): 167-172.

20. Fu H, Tie Y, Xu C, Zhang Z, Zhu J, Shi $Y$ \& Zheng X (2005). Identification of human fetal liver miRNAs by a novel method. FEBS letters 579(17): 38493854.

21. Lui WO, Pourmand N, Patterson BK \& Fire A (2007). Patterns of known and novel small RNAs in human cervical cancer. Cancer Res 67(13): 60316043.

22. Zhao S, Yao D, Chen J, Ding N \& Ren F (2015). MiR-20a promotes Cervical Cancer proliferation and metastasis in vitro and in vivo. PLOS ONE 10(3): e0120905.

23. Iorio MV, Ferracin M, Liu CG, Veronese A, Spizzo R, Sabbioni S, Magri E, Pedriali M, Fabbri M, Campiglio M, Ménard S, Palazzo JP, Rosenberg A, Musiani P, Volinia S, Nenci I, Calin GA, Querzoli P, Negrini M \& Croce CM (2005). MicroRNA gene expression deregulation in human breast cancer. Cancer Res 65 (16): 7065-70.

24. Kumarswamy R, Volkmann I \& Thum T (2011). Regulation and function of miRNA-21 in health and disease. RNA Biology 8(5): 706-713.

25. Lal A, Pan Y, Navarro F, Dykxhoorn DM, Moreau L, Meire E, Bentwich Z, Lieberman J \& Chowdhury D (2009). miR-24-mediated downregulation of H2AX suppresses DNA repair in terminally differentiated blood cells. Nat Struc Mol Biol 16(5): 492.

26. Qin W, Shi Y, Zhao B, Yao C, Jin L, Ma J \& Jin Y (2010) miR-24 Regulates apoptosis by targeting the open reading frame (ORF) region of FAF1 in cancer cells. PLOS ONE 5(2): e9429. 
27. Khodadadi-Jamayran A, Akgol-Oksuz B, Afanasyeva Y, Heguy A, Thompson M, Ray K, Giro-Perafita A, Sánchez I, $\mathrm{Wu}$ X, Tripathy D \& ZeleniuchJacquotte A (2018). Prognostic role of elevated mir-24-3p in breast cancer and its association with the metastatic process. Oncotarget 9(16): 12868.

28. Yan L, Ma J, Zhu Y, Zan J, Wang Z, Ling L, Li Q, Lv J, Qi S, Cao Y \& Liu Y (2018). miR-24-3p promotes cell migration and proliferation in lung cancer by targeting SOX7. J Cellular Biochem 119(5): 3989-3998.

29. Leung WK, He M, Chan AW, Law PT \& Wong N (2015). Wnt/ $\beta$-Catenin activates MiR-183/96/182 expression in hepatocellular carcinoma that promotes cell invasion. Cancer Letters 362(1): $97-$ 105.

30. Zhu W, Zhou K, Zha Y, Chen D, He J, Ma H, Liu X, Le H \& Zhang Y (2016). Diagnostic Value of Serum miR-182, miR-183, miR-210, and miR-126 Levels in Patients with Early-Stage Non-Small Cell Lung Cancer. PLOS ONE 11(4): e0153046.

31. Zhang Y, Li M, Wang H, Fisher WE, Lin PH, Yao Q \& Chen C (2009). Profiling of 95 microRNAs in pancreatic cancer cell lines and surgical specimens by realtime PCR analysis. World J Surg 33(4): 698.

32. Scheffer AR, Holdenrieder $S$, Kristiansen G, von Ruecker A, Müller SC \& Ellinger J (2014). Circulating microRNAs in serum: novel biomarkers for patients with bladder cancer?. World J Urol 32(2): 353-358.

33. Hong L, Han Y, Zhang H, Li M, Gong T, Sun L, Wu K, Zhao Q \& Fan, D. (2010). The prognostic and chemotherapeutic value of miR-296 in esophageal squamous cell carcinoma. Ann Surg 251(6): 1056-1063.
34. Wang W, Yang J, Xiang YY, Pi J \& Bian J (2017). Overexpression of Hsa-miR320 is associated with invasion and metastasis of ovarian cancer. J Cellu Biochem 118(11): 3654-3661.

35. Pepe F, Pagotto S, Soliman S, Rossi C, Lanuti P, Braconi C, Mariani-Costantini R, Visone R \& Veronese A (2017). Regulation of miR-483-3p by the Olinked $\mathrm{N}$-acetylglucosamine transferase links chemosensitivity to glucose metabolism in liver cancer cells. Oncogen 6(5): e328.

36. Hussein N, El Kholy ZA, Anwar MM, Ahmad MA \& Ahmad SM (2017). Plasma miR-22-3p, miR-642b-3p and miR-885-5p as diagnostic biomarkers for pancreatic cancer. J Can Res Clin Oncol 143(1): 83-93.

37. Zhang Y, Sui J, Shen X, Li C, Yao W, Hong W, Peng H, Pu Y, Yin L \& Liang $G$ (2017). Differential expression profiles of microRNAs as potential biomarkers for the early diagnosis of lung cancer. Oncol Rep 37(6): 35433553.

38. Chang J, Nicolas E, Marks D, Sander C, Lerro A, Buendia MA, Xu C, Mason WS, Moloshok T, Bort R \& Zaret KS (2004). miR-122, a mammalian liverspecific microRNA, is processed from hor mRNA and maydownregulate the high affinity cationic amino acid transporter CAT-1. RNA Biol 1(2): 106113.

39. Tang X, Gal J, Zhuang X, Wang W, Zhu $H$ \& Tang $G$ (2007). A simple array platform for microRNA analysis and its application in mouse tissues. RNA 13(10): 1803-1822.

40. Kutay H, Bai S, Datta J, Motiwala T, Pogribny I, Frankel W, Jacob ST \& Ghoshal K (2006). Downregulation of miR-122 in the rodent and human hepatocellular carcinomas. $J$ Cellu Biochem 99(3): 671-678. 
41. Murakami Y, Yasuda T, Saigo K, Urashima T, Toyoda H, Okanoue T \& Shimotohno K (2006). Comprehensive analysis of microRNA expression patterns in hepatocellular carcinoma and non-tumorous tissues. Oncogene 25: 2537-2545.

42. Henke JI, Goergen D, Zheng J, Song Y, Schuttler CG, Fehr C, Jünemann C \& Niepmann M (2008). microRNA-122 stimulates translation of hepatitis $\mathrm{C}$ virus RNA. EMBO J 27: 3300-3310.

43. Landgraf $P$, Rusu M, Sheridan R, Sewer A, Iovino N, Aravin A, Pfeffer S, Rice A, Kamphorst AO, Landthaler M \& Lin C (2007). A mammalian microRNA expression atlas based on small RNA library sequencing. Cell 129(7): 14011414.

44. Fazi F, Racanicchi S, Zardo G, Starnes LM, Mancini M, Travaglini L, Diverio
D, Ammatuna E, Cimino G, Lo-Coco F \& Grignani F (2007). Epigenetic silencing of the myelopoiesis regulator microRNA-223 by the AML1/ETO oncoprotein. Cancer Cell 12(5): 457466.

45. Stamatopoulos B, Meuleman N, HaibeKains B, Saussoy P, Van Den Neste E, Michaux L, Heimann P, Martiat P, Bron D \& Lagneaux L (2009). microRNA-29c and microRNA-223 down-regulation has in vivo significance in chronic lymphocytic leukemia and improves disease risk stratification. Blood 113(21): 5237-5245.

46. Wei LJ, Li JA, Bai DM \& Song Y (2018). miR-223-RhoB signaling pathway regulates the proliferation and apoptosis of colon adenocarcinoma. Chemico-Biological Interactions 289: 914. 